\title{
Role and Importance of the Damu Enterprise Development Fund and International Investment Funds in Implementing Project and Leasing Financing Programs in Kazakhstan
}

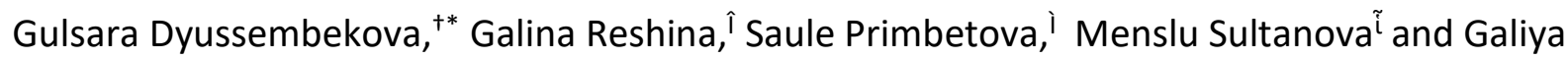 \\ Beisembayeva ${ }^{¥}$
}

\section{Abstract}

This article considers the loan indicators in the Republic of Kazakhstan and defines promising areas for the development of project and leasing financing of alternative investment instruments in infrastructure projects. The results of the research demonstrate that on the financial market of the Republic of Kazakhstan the volume of bank credit falls and the availability of capital decreases, which stipulates the attraction of alternative sources of financing for infrastructure projects. Prospective mechanisms of investing in projects of this kind include projects and leasing financing. It is noted that currently, the Republic of Kazakhstan is successfully cooperating with international financial companies and multilateral development banks to attract financial resources to implement investment projects. In spite of the existing leasing development potential, this mechanism for financing infrastructure projects is not entirely used. Stimulation of demand for leasing programs by corporate clients, the development of subsidy programs or guarantees to suppliers to purchase equipment, the reduction of the cost of funding, the development and implementation of project financing programs on the basis of syndication of loans are singled out as promising directions for the further development of project and leasing financing mechanisms.

Keywords: Project Financing, Financial Instruments, Multilateral Development Banks, International Companies, Leasing, Infrastructure Projects, Investments, Syndication of Loans

\footnotetext{
${ }^{\dagger}$ S. Toraighyrov Pavlodar State University, Lomov St., 64, Pavlodar, 140008, Kazakhstan

${ }^{*}$ Corresponding Author, Email: gulsara.dyusembekova@mail.ru

î Baltic International Academy, Lomonosov St., 4, Riga, LV-1019, Latvia

' M. Utemisov West Kazakhstan State University, Dostyk St., 162, Uralsk, 090009, Kazakhstan

¿ West Kazakhstan Agrarian-Technical University named Zhangir khan, Zhangir khan St., 51, Uralsk, 090009, Kazakhstan

¥ Bishkek Humanities University, Mira Av., 27, Bishkek, 720044, Kyrgyzstan

(C) 2019 Dyussembekova et al. This is an Open Access article distributed under the terms of the Creative Commons Attribution License (http://creativecommons.org/licenses/by/2.0), which permits unrestricted use, distribution, and reproduction in any medium, provided the original work is properly cited.
} 


\section{Introduction}

The most important factor of the favourable investment climate and the main objective for the development of cities in the Republic of Kazakhstan is the construction and modernisation of infrastructure facilities. Under the conditions of the limited access of Kazakh borrowers to long-term debt financing, the implementation of infrastructure projects is a serious problem.

On the emerging market of the Republic of Kazakhstan, it became possible to finance many projects only subject to the leading role of export credit institutions and multilateral financial institutions. However, today interest rates in tenge (Kazakh monetary unit) remain high, and the decline of oil prices has a negative impact on the Kazakh economy. These factors caused a decrease in the availability of capital and the increase in its price. Now major changes are taking place on the Kazakh crediting market: large market participants represented by banks have practically frozen lending to the population and the economy of the Republic of Kazakhstan.

While it is more and more difficult for commercial banks, which have historically provided priority financing for projects' debts obligations, to maintain their positions as the main providers of capital, there is a steady demand for alternative financial instruments project financing and leasing.

Creditors lend money for a project exclusively based on its risks and future cash flows. Thus, project financing is a method of financing when project creditors either do not have the recourse right or have a limited recourse right about the parent company that develops or "sponsors" the project (Groobey et al., 2010).

Besides, the development of leasing financing is of interest to the Republic of Kazakhstan. The essence of leasing is the creation of a comprehensive financial instrument that combines benefits of such financial instruments as the loan, instalments and leasing.
Even though in many countries project financing and leasing have become common methods of financing large infrastructure projects, these instruments are not fully used in the Republic of Kazakhstan.

This research attempts to describe the activity of the national fund of financing and international funds and multilateral development banks, as well as to define the main areas of cooperation in implementing project financing and leasing programs in the Republic of Kazakhstan.

The research is structured as follows-it begins with a discussion of a critical summary of the published scientific literature related to the topic studied in this article. The second section presents the research methodology. This section contains a description of the research process, as well as the selection and implementation of data collection methods. The third section presents the results of the analysis of the collected empirical materials. The fourth section contains a discussion in the context of existing problems and some suggestions for further work.

\section{Review of Literature}

Many works of foreign and domestic scientists including economists and lawyers were devoted to project financing and leasing relations' studies.

Despite the fact that the practice of project financing and leasing has considerably changed over the past decades, there is a low number of scientific studies (Sawant, 2010). It is even more surprising since a number of reputed authors including Benjamin Esty (2004) from the Harvard Business School and Professor Bent Flyvbjerg from the Oxford University's Saïd Business School (Flyvbjerg, Garbuio and Lovallo, n. d.) have shown the unique empirical advantages of PF (project financing) for research. Kardes notes the enormous complexity and scale of investments in PF, which makes them ideal for research to make managerial decisions at the borders, which is economically feasible (Kardes et al., 2013). 
Most infrastructure projects attract large-scale investments in the conditions of increasing uncertainty of the external environment (Hainz and Kleimeier, 2006). This makes projects too risky for corporate finances.

Back in 1996, Brealey et al. summarised some of these conclusions in the conceptual publication about advantages of investments in the form of project financing and leasing in infrastructure (Brealey, Cooper and Habib, 1996). This work was important in the sense that it recognised risk management strategies (that is, mitigating a political risk). After that Dailami and Leipziger (1997) presented the first major empirical attempt to test formal models in the quantitative research of credit spreads. Using infrastructure projects, they found that the ecological factors of the host country had a strong impact on credit risk and prices.

In 1999, Esty confirmed the advantages of PF related to natural resources of investing, using the studies of Petrozuata on oil deposits in Venezuela (Esty, 1999). He stated that, despite the high risk of investments, the project participants created sufficient risk management instruments.

Despite the scepticism about PF growing over the recent years, its structural advantages are still undeniable and empirically confirmed in subsequent quantitative studies (Blanc-Brude and Strange, 2007). Thus, the review of the literature allows us to form the theoretical basis of the study and creates a reasoned basis for conducting data analysis and obtaining empirically grounded conclusions and recommendations. The following section discusses the methods deployed for this research.

\section{Methods}

The purpose of this article is to research the trends in lending in the Republic of Kazakhstan and determine the prospects for the development of PF and leasing as alternative instruments for financing infrastructure projects.

The research was carried out using both qualitative and quantitative methods of analysis, methods of economic theory, including the method of comparing the dynamics of statistical indicators for eight years. The following was selected as analytical indicators characterising lending in the Republic of Kazakhstan:

- Internal lending to the private sector by banks (excluding the Central Bank) was referred to financial resources provided in the form of loans, credits, etc.

- Internal lending provided by the financial sector included all loans to various sectors on a gross basis, except for a central bank loan, and

- The flow of foreign direct investments (FDI). This indicator reflected the form of participation of foreign capital in the implementation of investment projects on the territory of the recipient country. Typically, FDI is long-term and rather large investments that allow a foreign investor to establish effective control over the enterprise management and create a long-term interest in its successful operation.

\section{Indicators of Project Financing of International Funds in the Republic of Kazakhstan}

Since as of the date of the study, there are no statistical indicators characterising the development of the financial sector of the Republic of Kazakhstan for 2018, the analysis covers the period of 8 years (2009-2017).

In the period from 2009 to 2016, domestic lending by the financial sector (\% of GDP) in the Republic of Kazakhstan decreased by 11 percentage points. The average annual change in the value of domestic lending by the financial sector (\% of GDP) in Russia for this period was $1.4 \%$ (Figure 1). The maximum value of domestic lending by the financial sector of the Republic of Kazakhstan was noted in 2009; the lowest was in 2014 (36.1\%).

In 2016, domestic lending by banks (\% of GDP) to the private sector in the Republic of Kazakhstan was $30 \%$, which was four percentage points more than in 2015 (34\%). Over the period from 2009 to 2016, this indicator in the Republic of Kazakhstan decreased by 20.3 percentage 
points. The average annual change in the value of domestic lending by banks (\% of GDP) to the private sector in Kazakhstan for this period was $2.5 \%$.

The stagnation of bank lending to the economy of the Republic of Kazakhstan is caused, first of all, by the lack of high quality and liquid security among the borrowers, the deterioration of the economy due to the unstable and unfavourable price for oil, as well as the alternative state system of preferential lending through such state holdings as Damu, Baiterek, KazAgro.

In 2016, a gross inflow of FDI to Kazakhstan increased by $40 \%$, as compared with 2015 , which amounted to $\$ 20.6$ billion.

In 2016, the inflow of FDI to the Republic of Kazakhstan increased 2.75 times, as compared with 2015, and amounted to $\$ 16.98$ billion. However, due to the increase in geopolitical risks in 2018, there was a sharp decrease in this indicator to 4.65 billion US dollars (Figure 2).

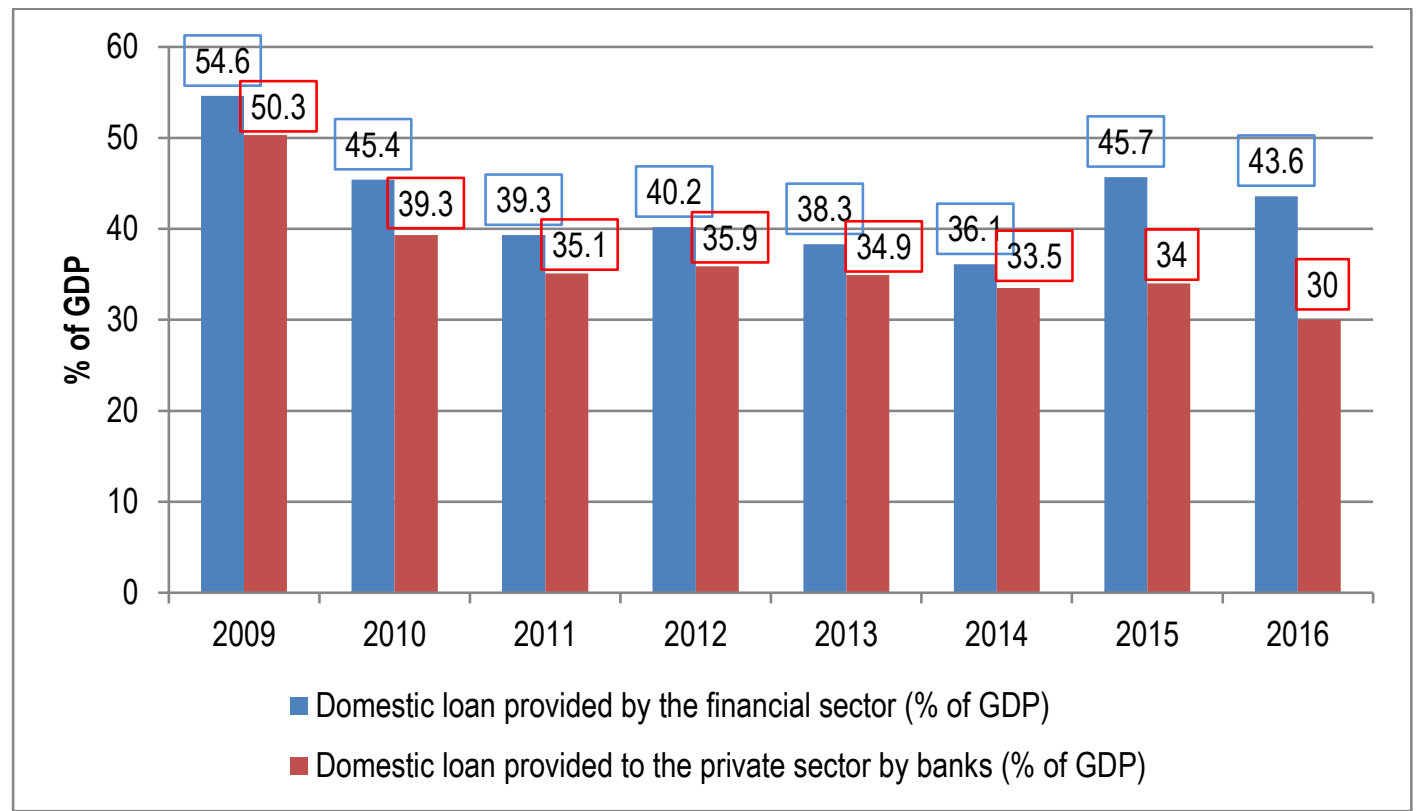

Figure 1: Dynamics of Providing Domestic Loans in the Republic of Kazakhstan (\% of GDP) in 2009-2016

Source: The World Bank, n. d. a

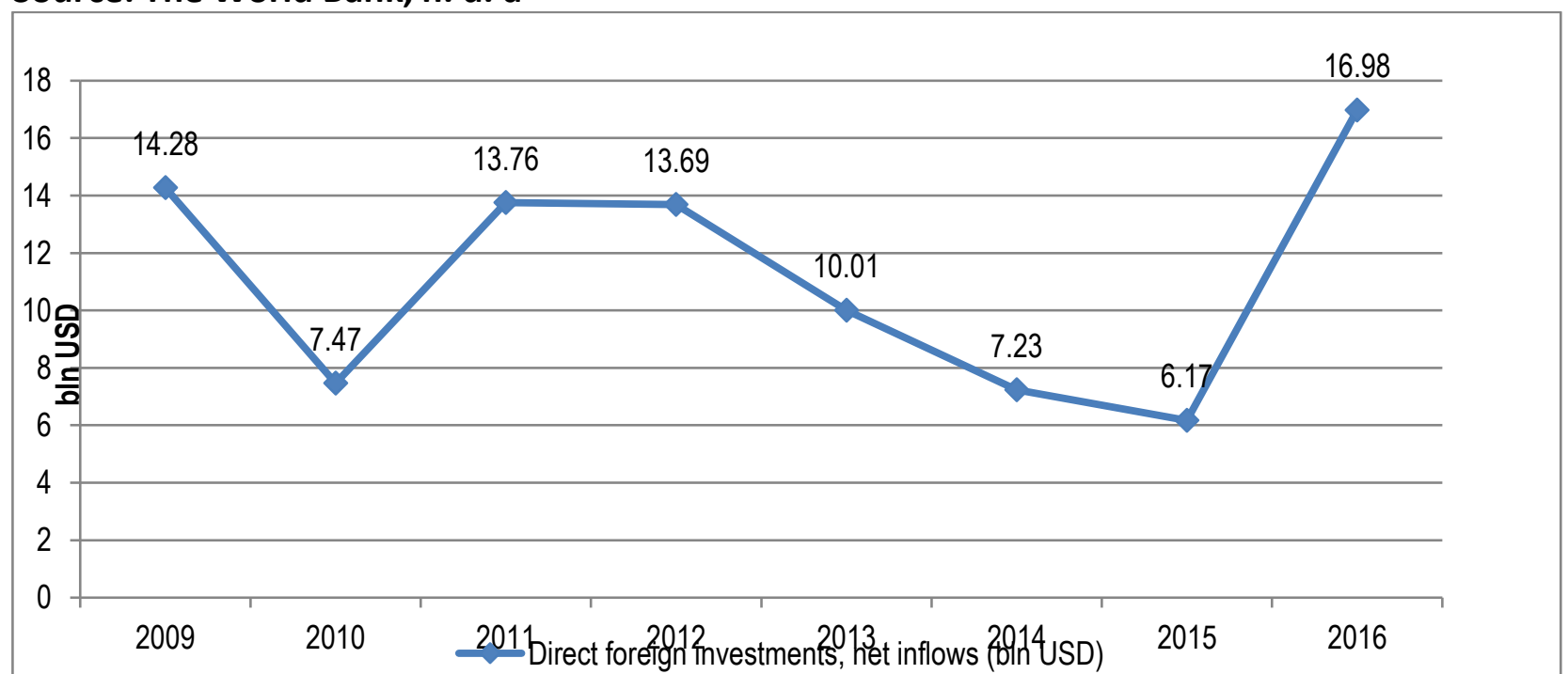

Figure 2: Dynamics of Net Inflows of FDI in the Republic of Kazakhstan in 2009-2016, bln USD Source: The World Bank, n. d. b 
Now financing of infrastructure projects in the Republic of Kazakhstan is carried out through:

- International and national funds,

- Second-tier banks,

- International financial organisations, and

- The State.

Commercial banks are still the main suppliers of debts for energy and infrastructure projects, but now they are joined by many other suppliers and products. Bank loans, private placements, government bonds, direct institutional debt, multilateral and export credit agencies are all now actively involved in this sector.

The National Financial Agency for Asset Management of the State is the Damu Entrepreneurship Development Fund that finances small and medium-sized businesses through second-tier banks (STB), leasing companies $(L C)$, microfinance organisations (MFOs), subsidising interest rates and guaranteeing loans within the activities defined in the "2020 Road Map of Business".

In 2016, the Damu Fund financed 10,145 borrowers for the total amount of loans of 247.3 billion tenges. The Fund guaranteed the funds of the European Bank for Reconstruction and Development in the amount of 22.3 billion tenges. In addition, for 2016, 2,121 projects for a total of 331.8 billion tenges were approved for the subsidy instrument of remuneration rates, which was $28 \%$ of the target level. By the instrument for guaranteeing loans, in 2016, 951 agreements were signed ( $136 \%$ of the plan).

The Fund actively raises funds from international financial organisations. In 2016, the Damu Fund concluded a loan agreement with the European Investment Bank to raise funds for not more than 200 million euros. As a result, as on 01 January 2017, 9,711 projects were funded from the international financial organisations (EBRD and $A D B$ ) for a total of 210.6 billion tenges, including 8,068 projects of 96.1 billion tenges in 2016.

In addition to the Damu Fund in the Republic of Kazakhstan, the US Trade and Development Agency (USTDA) provides funds for feasibility studies of major projects. USTDA has large experience in countries in transition, and the agency quickly started creating programs after Kazakhstan had become independent in 1991.

As on the beginning of 2015, the USTDA provided Kazakhstan with approximately $\$ 13$ million in the funds, and also financed a number of feasibility studies and technical assistance projects and sponsorship missions in the United States for major projects in key sectors such as oil and gas, railway transport, information technology, health and power. These projects that require considerable expenditures of foreign equipment and technologies will contribute to the development of Kazakh physical infrastructure. Feasibility studies, as a rule, assessment of the technical, economic, financial and environmental aspects of a project to determine how an investment project should be developed.

The respective Kazakh sponsoring organisation (government or private sector) must submit an official request for assistance directly to the USTDA in writing. If an American firm is already working with a Kazakh organisation, the American partner should submit a separate offer to the TDA in accordance with the USTDA draft.

The Republic of Kazakhstan implements the following projects under the support of USTDA:

- The project of JSC Alatau Zharyk companies (AGC) on automation of smart grid electricity distribution,

- Batys Transit JSC project to create a gas power plant in the northwest of Kazakhstan,

- Project for exploration, production and processing of helium, natural gas and nitrogen from the existing gas deposits in Zhambyl Region of Kazakhstan, implemented by Kaztransgaz JSC (KTG), and

- The Kazakhstan State Railway Company's project to optimise the railway network based on the modernisation and consolidation of information technology (IT) and information management systems. 
Project financing in the infrastructure projects of the Republic of Kazakhstan is also implemented through multilateral development banks, such as the European Bank for Reconstruction and Development, the European Investment Bank, the Asian Development Bank, the World Bank, the Islamic Development Bank, and the Asian Bank for Infrastructure Investments. These institutions allocate billions of dollars in the Republic of Kazakhstan to projects aimed at accelerating economic growth and social development by reducing poverty and inequality, improving health and education and promoting infrastructure development.

One of the main sources of foreign aid to Kazakhstan is the World Bank. It has provided the Republic of Kazakhstan with more than 41 loans amounting a total of more than 6.8 billion dollars. The World Bank's support is currently focused on investment projects that include agricultural development, environmental protection, health and general infrastructure.

Since 2002, the World Bank and the Government of Kazakhstan have been jointly financing and implementing a multiyear program of joint economic research (JERP). The program efficiently carried out strategic research on key areas of policy development. The current topics include the reform of public financial management, municipal reform, professional education, the introduction of international financial reporting standards, public-private partnerships and the country's pension and social systems.

Since Kazakhstan became a member of the Islamic Development Bank (IDB) in 1995, it had obtained nearly $\$ 2.1$ billion in 31 projects. Significant resources are directed to insurance and development of state and private sector, including the establishment of the AIFC. The Bank also financed $\$ 800$ million in foreign trade to promote trade among its member countries.

The European Investment Bank (EIB) began its lending activity in Kazakhstan in 2014, and currently, the volume of loans has reached EUR 220 million. The EIB is primarily involved in supporting small and medium-sized enterprises (SMEs) and companies with the medium market capitalisation, social infrastructure development, environmental protection and mitigation of climate change. Through its program in Central Asia, the EIB also financed projects for RES, transportation and storage.

Since 1993, Kazakhstan has been the largest client of the International Finance Corporation (IFC) in Central Asia. IFC supports the development of the financial sector of the country and provides financial institutions with a full range of investments. Since 1997, IFC has provided a number of commercial banks, including microfinance and leasing companies, with more than $\$ 1.4$ billion of investments in Kazakhstan through equity participation, quasiequity products, and senior debt and financial trading products.

One of the largest international investors that finance projects outside the Kazakh oil and gas sector are the European Bank for Reconstruction and Development (EBRD). This financial institution supports the implementation of the Kazakh economy diversification strategy, financial restructuring, capital markets and infrastructure.

$47 \%$ of the EBRD loan portfolio is invested in infrastructure projects, $32 \%$ - in the energy sector, $15 \%$ - in industry, commerce and agriculture, and $6 \%$ - in financial institutions. Over the past two years, the EBRD has also invested in infrastructure, transport, energy, utilities and the banking sector.

From 2015 to 2017, the volume of investments in the municipal infrastructure sector of the Republic of Kazakhstan amounted to \$339 million (178 billion tenges) for 21 projects, including:

- Urban transport - 63.5 billion tenges, seven projects,

- Irrigation - 50.5 billion tenges, one project,

- Heat supply - 32.9 billion tenges, nine projects,

- Water supply and sanitation -27.8 billion tenges, 12 projects, and

- Street illumination -3.1 billion tenges, one project. 
In 2015-2017, the EBRD implemented three technical support programs. Together with the Government of the Republic of Kazakhstan, it ensured the use of 17 billion tenges of cofinancing resources of the Government of the Republic. In December 2017, the EBRD and the Government of the Republic of Kazakhstan extended the Framework Agreement on Cooperation for another three years. The EBRD is considering the possibility of expanding investment in the municipal sector.

Since 1994, the Republic of Kazakhstan is a member of the Asian Development Bank (ADB). Since then, the country has received over $\$ 5$ billion as sovereign and non-sovereign loans in the agriculture, education, finance, transport and communications, water supply, sanitation and irrigation sectors. The aggregate amount of state-guaranteed loans of the ADB in Kazakhstan is approximately $\$ 4.6$ billion, and additionally $\$ 455.2$ million of non-guaranteed loans and guarantees.

ADB also participates in project financing in partnership with government agencies, multilateral financial institutions and commercial organisations.

In accordance with the new country cooperation strategy between Kazakhstan and ADB for 20172021 (Asian Development Bank, 2017), the ADB will finance the private sector of Kazakhstan. Over the next five years, the international organisation will support Kazakhstan in the amount of more than $\$ 3$ billion. Along with financing key social and urban infrastructure facilities, the fund will provide access to preferential financing for small and mediumsized public utilities in Kazakhstan. The cooperation between the international financial institution and Kazakhstan is planned in agriculture, health care, and the development of renewable energy sources.

In 2014, the Republic of Kazakhstan had become a co-founder of the new international financial institution - the Asian Infrastructure Investment Bank (AIIB). The newly established multilateral development bank began its activity in early 2016. Its main directions are the development of infrastructure and other production sectors in
Asia, including energy and electricity, transportation and telecommunications, rural infrastructure and agricultural development, water supply and sanitation, environmental protection, urban development and logistics. The AlIB can create special funds for direct financing of special-purpose projects. There are such funds, for example, in the ADB.

In December 2016, the Board of Directors of AllB approved a private solar energy project in the amount of $\$ 69$ million. It will be cofinanced jointly with the EBRD. The project will increase the potential of renewable energy sources in the remote southern region of Kazakhstan and reduce the republic's dependence on coal to meet the growing demand for electricity.

\section{Discussion}

EBRD experts note that municipal enterprises of the Republic of Kazakhstan that manage solid municipal wastes, urban transport, the energy efficiency of municipal infrastructure facilities need additional financing (The EBRD is a partner of the Government of Kazakhstan in the municipal infrastructure sector, 2018).

Project and leasing financing of SMEs can become efficient instruments for attracting investments to infrastructure facilities of the Republic of Kazakhstan. Strategic areas for financial support of SMEs are implemented by Damu, the national fund of the Republic of Kazakhstan.

According to the studies, the leasing market is the most promising for financing the country's economy, but it requires a certain "reset" (LLP "EXIMAR", n.d.). In general, in 2016 the capacity of the leasing market for new transactions (transfer to financial leasing) reached 104 billion tenges or $47 \%$ of the current leasing portfolio. The leasing terms decreased to an average of 5 years instead of the previously practised 7-10 years.

As on the beginning of 2017, in the Republic of Kazakhstan, there were 24 resident players operating on the Kazakh leasing market, which by their type were divided into the following groups of companies: 
Leasing companies as a part of banking holdings (11 companies including 1 Islamic company - JSC Al Sakr Finance),

Leasing companies of national development institutions $(3$, including the residual direct portfolio of $D A M U)$,

Independent leasing companies (6 companies including 1 Islamic company - LLP Company ljara Kazakhstan), and

Leasing companies of equipment and machinery suppliers (4 specialised leasing companies in partnership with dealers of machinery and equipment).

In order to stimulate the economic activity of SMEs, the Damu-Leasing Fund has developed and implements a financial leasing program. The program is implemented at the expense of the fund's own resources. According to the terms and conditions of the program, the term of the leasing transaction should not exceed 84 months and the interest rate should not be more than $14 \%$. Within the program, a tax concession period for the repayment of the principal debt (PD) for a period of up to 1 year is provided. For one SME entity, the maximum financing limit is set at $\mathbf{1 5 0}$ million tenges. At the same time, the total amount of financial leasing agreement may exceed this amount due to an advance payment. The initial instalment is $20 \%$ of the value of the fixed asset.

SMEs who cannot participate in the Damu Fund's leasing program include those that:

- Aim at refinancing leasing transactions,

- Have debts on taxes and other mandatory payments to the state budget,

Use the leaseback. The leaseback means that first, the owner of the property sells it to the future lessor, and then he himself rents the same object from the buyer, that is, the same person acts both as a seller and as a lessee. As a result, only the owner of the equipment changes, and its use remains the same, having received additional funds at his disposal,

Uses secondary leasing - the type of leasing when the main asset that remains with the lessor in case of terminating and dissolving the leasing agreement is leased to another lessee, and

- Use subleasing - the type of sublease of the leased asset, when the lessee under the agreement transfers to the third parties (lessees under the subleasing contract) to possess and use for a fee and for a period of time in accordance with the terms and conditions of the subleasing agreement the property previously obtained from the lessor under the leasing agreement and that is the subject of leasing.

In general, many market participants note that the leasing mechanism for the implementation of infrastructure projects in the Republic of Kazakhstan is poorly developed. The expert community notes that leasing is instead a large sector of the financial system of the Republic of Kazakhstan, but at the same time, it remains relatively opaque. Experts believe that the main goal of developing the Kazakh leasing market is to improve the competitiveness of leasing as compared with the bank loan. One of the key problems is the raising of funding, the priority of reforming the market should be to expand access to bank lending and other sources of financing.

According to market participants, the growth of demand from customers that at the moment is primarily focused on transport equipment can have a positive impact on the development of leasing in the Republic of Kazakhstan. Efficient subsidy programs or suppliers' guarantees for repurchasing equipment can become drivers of this segment. The reduction in the cost of funding or high-tech equipment can also contribute to the development of this leasing segment.

The development of project financing is a promising source of attracting investments in infrastructure projects. Within the development of project financing in cooperation with the ADB and the World Bank, the Republic of Kazakhstan plans to establish a municipal infrastructure fund to support urban infrastructure and companies in the field of municipal services. One of the tasks declared by the ADB at the new stage of 
cooperation with Kazakhstan is to increase the participation of the private sector in updating and developing the infrastructure of Kazakhstan. It goes about the implementation of projects in a combined format of both state (sovereign) and nonsovereign project financing. Thus, the private sector of Kazakhstan will have access to cheap long-term financing, instead of attracting borrowed funds at high-interest rates that under current conditions may be $14-15 \%$.

One of the most promising mechanisms for project financing of infrastructure facilities can be the development of cooperation on programs for syndicated loan projects. Syndication of loans (or syndicated loans) is a method of financing when one or more banks (the so-called syndicate) lend funds to the same borrower and for the same project. Syndicated loans have the following common features:

- Assuming a substantial credit for a more extended period;

- Distributing the risk of making a loan among several banks;

- All parties agree to the single loan agreement; and

- Reducing the cost of debt to the borrower due to the distribution of risks.

Syndication of loans is common when it comes to financing large-scale energy and infrastructure projects. The loan syndication usually includes a credit bank that fulfils functions of a project operator and manages the project, along with other credit banks that have signed the loan project agreement.

\section{Conclusion}

According to experts, in the coming years, the leasing market will maintain considerable unsatisfied demand for loan resources, especially for financing non-resource sectors of the economy. Thus, in the medium and long term, the demand for leasing financing from the corporate sector is expected to grow in order to modernise business and develop new projects.

It is necessary to actively develop cooperation with international financial organisations and multilateral development banks in the area of concession projects, the creation of mechanisms for project financing of infrastructure facilities on the basis of a syndicated loan.

Since Kazakhstan is ready for large-scale development in the area of infrastructure development and energy production, syndication of loans can play a vital role in financing projects.

\section{References}

Asian Development Bank. (2017). Sodeystviye diversifikatsii ekonomiki, inklyuzivnomu razvitiyu i ustoychivomu rostu. Kazakhstan, 2017-2021 gg. [Contributing economic diversification, inclusive development and sustainable growth. Kazakhstan, 20172021]. Retrieved November 14, 2018 from https://www.adb.org/documents/kazakhst an-country-partnership-strategy-20172021.

Blanc-Brude, F., and Strange, R. (2007). How banks price loans to public-private partnerships: evidence from the european markets. J Appl Corp Financ, 19, 94-106.

Brealey, R. A., Cooper, I. A., and Habib, M. A. (1996). Using project finance to fund infrastructure investments. J Appl Corp Financ, 9, 25-39.

Dailami, M., and Leipziger, D. (1997). Infrastructure project finance and capital flows: a new perspective. In World bank policy research working paper (Vol. 1861). Washington, USA: World Bank.

\section{EBRR - Partnor Pravitelstva Kazakhstana v} sektore munitsipalnoy infrastruktury [The EBRD is a partner of the Government of Kazakhstan in the municipal infrastructure sector]. (2018). Retrieved November 14, 2018 from http://www.urbaneconomics.ru/sites/defa ult/files/1_31-01-

18_presentation_miroshnik_ebrd.pdf.

Esty, B. C. (1999). Petrozuata: a case study of effective use of project finance. J Appl Corp Financ, 12, 26-42. 
Esty, B. C. (2004). Why study large projects? An introduction to research on project finance. Eur Financ Manag, 10, 213-224.

Flyvbjerg, B., Garbuio, M., and Lovallo, D. (n. d.) Delusion and deception in large infrastructure projects: two models for explaining and preventing executive disaster. Calif Manag Rev, 51, 170-193.

Groobey, C., Pierce, J., Faber, M. and Broome, G. (2010). Project Finance Primer for Renewable Energy and Clean Tech Projects. Wilson Sonsini Goodrich \& Rosati. Retrieved November 14, 2018 from https://pdf4.pro/pdf/project-financeprimer-for-renewable-energy-and421539.pdf.

Hainz, C., and Kleimeier, S. (2006). Project finance as a risk-management tool in international syndicated lending: Discussion paper on governance and the efficiency of economic systems. Munich, Germany: Center for Economic Studies and Ifo Institute for Economic Research.
Kardes, I., Ozturk, A., Cavusgil, S. T. and Cavusgil, E. (2013). Managing global megaprojects: complexity and risk management. Int Bus Rev, 22, 905-917.

LLP “EXIMAR”. (n.d.). Perspektivy lizinga v Kazakhstane [Leasing prospects in Kazakhstan]. Retrieved November 14, 2018 from http://www.eximar.kz/index.php/2uncategorised/218-perspektivy-lizinga-vkazakhstane.

Sawant, R. J. (2010). The economics of largescale infrastructure FDI: the case of project finance. J Int Bus Stud, 41, 1036-1055.

The World Bank. (n. d. a). Domestic credit provided by financial sector (\% of GDP). Retrieved November 21, 2018 from https://data.worldbank.org/indicator/FS.AS T.DOMS.GD.ZS.

The World Bank. (n. d. b). Foreign direct investment, net inflows (BoP, current US\$). Retrieved November 21, 2018 from https://data.worldbank.org/indicator/BX.KL T.DINV.CD.WD?end=2017\&start=2016\&yea r_high_desc=false. 